\title{
Effects of octane derivatives on activity of the volume-regulated anion channel in rat pancreatic $\beta$-cells
}

\author{
Len Best ${ }^{1}$, Peter D. Brown \\ Faculties of Medical ${ }^{1}$ and Life Sciences, University of Manchester, Oxford Road, Manchester, M13 9WL, UK \\ Correspondence: Len Best, e-mail: Leonard.Best2@ntlworld.com
}

\begin{abstract}
:
Background: Saturated free fatty acids (FFAs) have a dual action on pancreatic $\beta$-cells, consisting of an initial enhancement and subsequent suppression of glucose-induced electrical activity and insulin release. These stimulatory and inhibitory effects have been attributed, at least in part, to the activation and inhibition, respectively, of the volume-regulated anion channel (VRAC) by FFAs. Both effects were independent of their metabolism. We have now investigated the effects of related aliphatic compounds in order to further define the determinants of FFA interaction with VRAC.

Methods: $\beta$-Cell VRAC and electrical activity were measured by conventional whole-cell and perforated patch recording, respectively. Cell volume was measured using a video-imaging technique.

Results: In common with octanoic acid, addition of methyl octanoate or n-octanol resulted in a rapid, pronounced and reversible inhibition of VRAC activity. Addition of n-octane had no significant effect on VRAC activity. n-Octanol had a biphasic effect on $\beta$-cell membrane potential, namely a small transient depolarization followed by a marked hyperpolarization. n-Octanol was also found to prevent regulatory volume decrease in cells exposed to a hypotonic medium, consistent with VRAC inhibition.

Conclusion: It is suggested that methyl octanoate and n-octanol can mimic the effects of FFAs on the pancreatic $\beta$-cell via modulation of VRAC activity. The structural requirements for this effect appear to be a medium or long chain aliphatic compound containing at least one oxygen atom.
\end{abstract}

Key words:

islet, pancreatic $\beta$-cell, electrical activity, cell volume, anion channel, octanol

\section{Introduction}

In a recent study, we demonstrated a dual action of saturated free fatty acids (FFAs) on electrical activity in rat pancreatic $\beta$-cells [5]. The effects of FFAs consisted of an initial enhancement and subsequent suppression of glucose-induced electrical activity, and were attributed predominantly to the activation, followed by an inhibition, of the volume-regulated anion channel (VRAC). The putative role of this conductance in the pancreatic $\beta$-cell has been reviewed elsewhere $[4,6]$. Briefly, VRAC activation results in $\mathrm{Cl}^{-}$ efflux generating an inward (depolarizing) current. Glucose and several stimuli of $\beta$-cell function have been shown to activate the conductance, possibly as a result of increased $\beta$-cell volume $[4,6]$. VRAC activation could subsequently contribute towards electrical and secretory activity. In addition to VRAC activation, other mechanisms of action of FFAs on $\beta$-cell 
function have been proposed, including interaction with the GPR40 receptor (see $[10,11]$ for reviews). Modulation of VRAC activity was observed with FFAs of eight or more carbons and did not appear to require their metabolism, implying a possible biophysical interaction between FFAs and the channel protein. This idea is at variance with the previous suggestion that FFAs affect $\beta$-cell function via their metabolism $[10,11]$. In order to further investigate the determinants of FFA interaction with the VRAC, we have extended our studies to a number of closely related aliphatic compounds.

\section{Materials and Methods}

Sodium octanoate, methyl octanoate, n-octanol and n-octane were purchased from the Sigma Chemical Co., Poole, UK.

Pancreatic $\beta$-cells were isolated from fed SpragueDawley rats (either sex, 300-350 g) and cultured in Minimal Essential Medium as described previously [3]. Cells were superfused with a bath solution consisting of (mmol/l) $130 \mathrm{NaCl}, 4 \mathrm{KCl}, 1 \mathrm{MgCl}_{2}, 1.2$ $\mathrm{CaCl}_{2}, 4$ glucose and 20 HEPES-NaOH (pH 7.4). nOctane and its derivatives were added at the required concentration (in most cases, $1 \mathrm{mmol} / \mathrm{l}$ ); all were found to be miscible with water at this concentration. The chemical structures of these compounds are shown in Figure 1.

Activity of the VRAC was recorded at the wholecell level using the conventional whole-cell recording technique with a List EPC-7 amplifier. A hypertonic pipette solution consisting of (mmol/l) $60 \mathrm{CsCl}, 2 \mathrm{MgCl}_{2}$, 1 ATP, 1 EGTA, 220 mannitol and 10 HEPES (pH 7.2) was used to swell the cells and thereby cause VRAC activation. $1 \mathrm{mmol} / 1 \mathrm{CsCl}$ was added to the bath solution to block inward $\mathrm{K}^{+}$currents. Currents
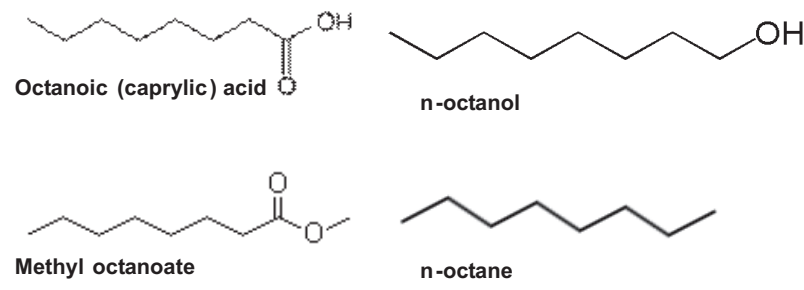

Fig. 1. Structures of the compounds used in the study were evoked by $50 \mathrm{~ms}$ voltage pulses of $\pm 100 \mathrm{mV}$ at $2 \mathrm{~s}$ intervals from a holding potential of $0 \mathrm{mV}$. Cell capacitance was measured by nulling the capacitance transients, and current density expressed as $\mathrm{pA} / \mathrm{pF}$. $\beta$-Cell membrane potential was recorded using the perforated patch technique essentially as described previously [2]. In these experiments, the pipette solution contained (mmol/l) $130 \mathrm{KCl}, 4 \mathrm{NaCl}, 1 \mathrm{MgCl}_{2}$, 10 HEPES-NaOH (pH 7.2) and $50 \mu \mathrm{g} / \mathrm{ml}$ gramicidin $\mathrm{D}$ as perforating agent.

Relative cell volume was measured using a videoimaging technique $[5,9]$. $\beta$-Cells were superfused with the isotonic $\left(291 \pm 1 \mathrm{mosmol} / \mathrm{Kg} \mathrm{H}_{2} \mathrm{O}\right)$ bath solution containing $4 \mathrm{mM} / 1$ glucose. Cell swelling was evoked by exposure to hypotonic solutions of either $213 \pm 1$ mosmol/ $\mathrm{Kg} \mathrm{H}_{2} \mathrm{O}$ or $187 \pm 2 \mathrm{mosmol} / \mathrm{Kg} \mathrm{H}_{2} \mathrm{O}$ produced by dilution of the isotonic solution with water.

All data are expressed as the means \pm SEM and statistical significance was ascribed using Student's paired $t$-test or by ANOVA where appropriate.

\section{Results}

The effects of n-octane derivatives on whole-cell VRAC activity in pancreatic $\beta$-cells are illustrated in
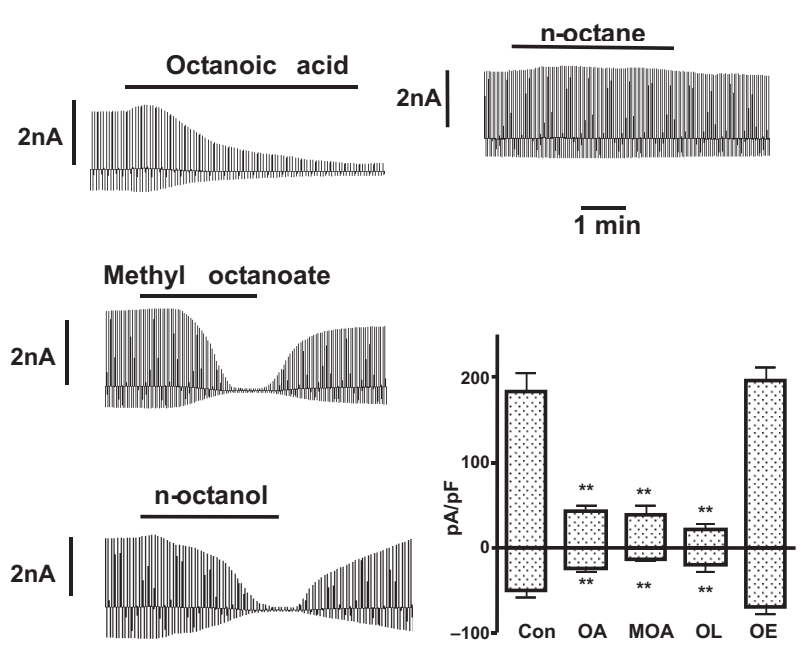

Fig. 2. Effects of medium chain aliphatic compounds on whole-cell VRAC activity in rat pancreatic $\beta$-cells. Octanoic acid (OA), methyl octanoate (MOA), n-octanol (OL) and n-octane (OE) were added at a final concentration of $1 \mathrm{mmol} / \mathrm{l}$. The recordings shown are typical of those from 4-12 experiments. The histograms show maximal inhibitory effects of these compounds, and represent the mean \pm SEM values from $4-12$ recordings. ${ }^{* *} p<0.001$ 


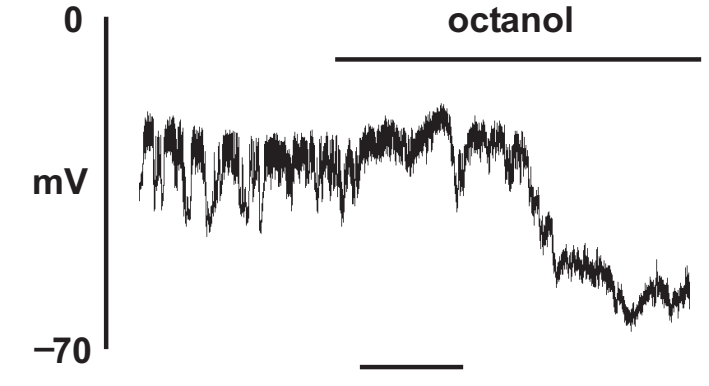

$1 \mathrm{~min}$

Fig. 3. Effect of $\mathrm{n}$-octanol $(1 \mathrm{mmol} / \mathrm{l})$ on membrane potential in a pancreatic $\beta$-cell. The glucose concentration was $16 \mathrm{mmol} / \mathrm{l}$. Essentially similar results were obtained in a total of 3 cells

Figure 2. The addition of octanoic acid caused a brief, initial activation of the conductance which was followed by a gradual and prolonged inactivation, as previously described [5]. By comparison, addition of methyl octanoate or n-octanol resulted in a relatively rapid and marked inhibition of VRAC activity. In 8 of the 14 cells used in these experiments (with either compound), the inhibition was preceded by an apparent, though modest activation of the conductance. However, in contrast to the stimulatory effect of octanoate, the initial effects of methyl octanoate and $\mathrm{n}$-octanol were not statistically significant $(\mathrm{p}>0.05)$. The secondary inhibition of VRAC activity evoked by octanoic acid persisted for a considerable period following its withdrawal from the medium. In contrast, the inhibitory effects of methyl octanol and of noctanol were rapidly reversible following withdrawal of these compounds. Addition of n-octane had no significant effect on VRAC activity. Figure 2 also shows quantified inhibitory effects of the above compounds (all $1 \mathrm{mmol} / \mathrm{l}$ ) on whole-cell VRAC activity. Inhibition of VRAC activity was also observed when these substances were used at a lower concentration of $0.2 \mathrm{mmol} / \mathrm{l}$, although in such cases, the rate of inhibition was considerably reduced (data not shown).

The effects of n-octanol on $\beta$-cell membrane potential were examined using the perforated patch recording technique. In the presence of a stimulatory concentration of glucose $(16 \mathrm{mmol} / \mathrm{l})$, a pattern of electrical activity was apparent, consisting of slow oscillations in membrane potential with superimposed action potentials (Fig. 3). The application of $1 \mathrm{mmol} / \mathrm{l} \mathrm{n}$-octanol caused a small initial, transient depolarization of the membrane potential followed by a marked hyperpolarization.
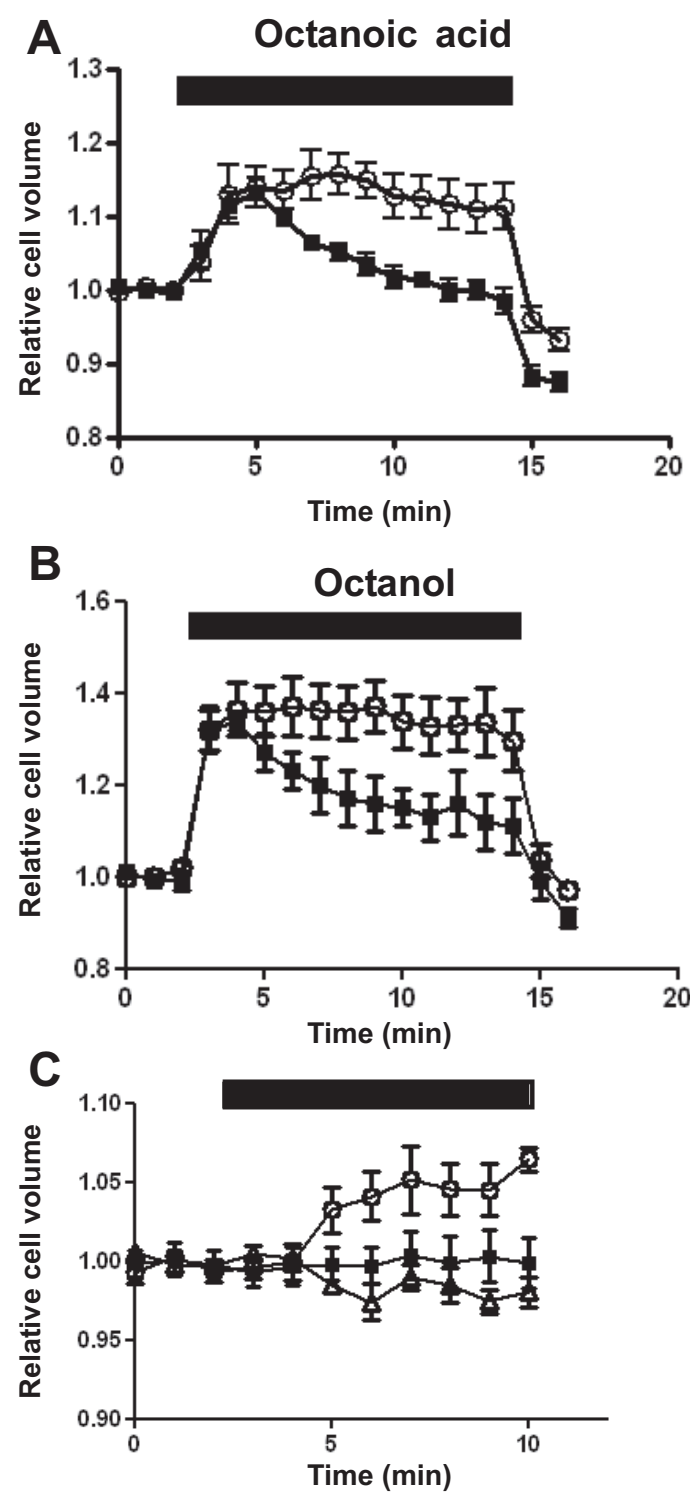

Fig. 4. Panels $\mathbf{A}$ and $\mathbf{B}$ : Inhibition of regulatory volume decrease by octanoic acid and n-octanol. Cells were superfused with a hypotonic medium (213 mosmol/ $\mathrm{Kg} \mathrm{H}_{2} \mathrm{O}$; A or $187 \mathrm{mosmol} / \mathrm{Kg} \mathrm{H}_{2} \mathrm{O}$; $\mathrm{B}$ ) for the period indicated by the bars. Experiments were performed in the absence (solid squares) or presence of octanoic acid or n-octanol (open circles; both $1 \mathrm{mmol} / \mathrm{l}$ ). Panel C: Effects of n-octanol (open circles) and octanoic acid (triangles) under isotonic conditions. The data are the means \pm SEM obtained from $4-5$ cells

The effects of octanoic acid and n-octanol on $\beta$-cell volume are shown in Figure 4. In control experiments, exposure of the cells to a hypotonic medium caused a prompt increase in relative cell volume (RCV) to a mean value of $1.15 \pm 0.02(\mathrm{n}=5$; A) or $1.34 \pm 0.02$ $(n=4 ; B)$. This was followed by regulatory volume decrease (RVD) to mean relative volume of either $0.98 \pm 0.02$ (A) or $1.11 \pm 0.06$ (B). As previously re- 
ported [5], the RVD response was abolished in the presence of octanoic acid (Fig. 4A). Inhibition of RVD was also observed in the presence of n-octanol (Fig. 4B). In both cases, cell volumes returned control values when returned to the isosmotic medium. As shown in Figure 4C, the application of n-octanol under isosmotic conditions was found to cause a significant increase in cell volume over $5 \mathrm{~min}(1.06 \pm 0.01$, $\mathrm{n}=4 ; \mathrm{p}<0.05$ by ANOVA compared to control 0.999 $\pm 0.01, \mathrm{n}=4)$. By contrast, octanoic acid had no significant effect on cell volume in isotonic solutions over $5 \mathrm{~min}(0.98 \pm 0.01)$. The increase in cell volume observed following the addition of n-octanol under isotonic conditions has not previously been recorded with other VRAC inhibitors. We suggest that this phenomenon reflects the high effectiveness of n-octanol as a VRAC inhibitor, and is consistent with the suggestion that the conductance in $\beta$-cells is active even under isosmotic conditions [7].

\section{Discussion}

The VRAC conductance appears to play an important role in the modulation of electrical, and hence secretory activity in pancreatic $\beta$-cells $[4,6]$. In general, activation of the conductance generates a depolarizing current leading to enhanced electrical activity, whilst VRAC blockers hyperpolarize the cell and inhibit $\beta$-cell function. We recently found evidence that the acute stimulatory and long-term inhibitory effects of FFAs on the $\beta$-cell could be due, at least in part, to a dual action on VRAC activity [5]. Neither the stimulatory nor inhibitory effect of FFAs appeared to require their metabolism.

In the present study, we have further defined the determinants of VRAC modulation by using a range of structurally related aliphatic compounds. Of these, methyl octanoate and n-octanol exerted rapid and pronounced inhibitory effects on VRAC activity. In approximately $50 \%$ of cells examined, this inhibitory action appeared to be preceded by a brief activation of the conductance, though this effect failed to reach statistical significance. It was interesting to note that the inhibitory effects of methyl octanoate and n-octanol were more rapidly reversible than was the case with octanoic acid. The reasons for this are unclear at present but could be related to the greater ease of move- ment of less polar compounds into and across the plasma membrane. It is also notable that n-octane failed to affect VRAC activity. Thus, the minimal determinant for VRAC modulation by FFAs and related compounds appears to be a medium chain length aliphatic compound containing at least one oxygen atom. In view of the fact that several known VRAC inhibitors are negatively charged organic molecules $[4,6]$, it is also noteworthy that a charged monocarboxyl group was not a prerequisite for VRAC inhibition by these eight-carbon compounds.

The modulation of VRAC activity by FFAs previously reported was closely associated with a dual action on $\beta$-cell electrical activity [5]. In the present study by comparison, n-octanol evoked an initial depolarization followed by a subsequent hyperpolarization. We suggest that these actions were likely due, respectively, to the transient activation of VRAC apparent in some cells and the subsequent marked hyperpolarization.

In addition to playing an important role in modulating $\beta$-cell membrane potential and electrical activity, the VRAC is also involved in the regulation of cell volume $[4,6]$. Thus, activation of the conductance as a result of cell swelling leads to $\mathrm{Cl}^{-}$efflux and hence regulatory volume decrease (RVD). Consistent with this mechanism, inhibition of VRAC by n-octanol was found to abolish RVD, an effect previously observed with a range of other VRAC blockers [4, 6]. We should point out that these functional studies of membrane potential and volume regulation were restricted to using n-octanol; the actions of other aliphatic compounds were not investigated.

Medium chain length alcohols, including n-octanol, have previously been reported to block gap junction channels $[8,12]$. These channels appear to be distinct from VRAC, however, at least on the basis of their kinetics and ion selectivity $[1,13]$. It should be pointed out that the molecular identity of VRAC channels remains unclear at present. It is possible that the powerful inhibition of VRAC by octane derivatives might assist with eventual identification of the channel protein(s).

\section{References:}

1. Beblo DA, Veenstra RD: Monovalent cation permeation through the connexin 40 gap junction channel. $\mathrm{Cs}, \mathrm{Rb}$, $\mathrm{K}, \mathrm{Na}, \mathrm{Li}$, TEA, TMA, TBA, and effects of anions $\mathrm{Br}$, 
$\mathrm{Cl}, \mathrm{F}$, acetate, aspartate, glutamate, and $\mathrm{NO}_{3}$. J Gen Physiol, 1997, 109, 509-522.

2. Best L: Glucose-induced electrical activity in rat pancreatic $\beta$-cells: dependence on intracellular chloride concentration. J Physiol, 2005, 568, 137-144.

3. Best L. In: Primary culture of pancreatic $\beta$-cells. Handbooks in Practical Animal Cell Biology; Endocrine Cell Culture. Ed. Bidey SP, Cambridge University Press, 1998, 62-73.

4. Best L, Brown PD, Sener A, Malaisse WJ: Electrical activity in pancreatic islet cells: The VRAC hypothesis. Islets, 2010, 2, 59-64.

5. Best L, Jarman EA, Brown PD: A dual action of saturated fatty acids on electrical activity in rat pancreatic $\beta$-cells. Role of volume-regulated anion channel and $\mathrm{K}_{\text {ATP }}$ channel currents. J Physiol, 2011, 589, 1307-1316.

6. Best L, McLaughlin J: In: Nutrients as Regulators of Endocrine and Neuroendocrine Secretion. Topics in Current Genetics, Ed. Taylor P, Winderickx J, Springer-Verlag, New York, 2004, 79-111.

7. Best L, Miley HE, Yates AP: Activation of an anion conductance and $\beta$-cell depolarization during hypotonically induced insulin release. Exp Physiol, 1996, 81, 927-933.
8. Bodendiek SB, Raman G: Connexin modulators and their potential targets under the magnifying glass. Curr Med Chem, 2010, 17, 4191-4230.

9. Miley HE, Sheader EA. Brown PD, Best L: Glucoseinduced swelling in rat pancreatic islets. J Physiol, 1997, 504, 191-198.

10. Nolan CJ, Madiraju MSR, Delghingaro-Augusto V, Peyot M-L, Prentki M: Fatty acid signalling in the $\beta$-cell and insulin secretion. Diabetes, 2006, 55, Suppl 2, S16-S23.

11. Poitout V: The ins and outs of fatty acids on the pancreatic $\beta$-cell. Trends Endocrinol Metab, 2003, 14, 201-203.

12. Spray DC, Ginzberg RD, Morales EA, Gatmaitan Z, Arias IM: Electrophysiological properties of gap junctions between dissociated pairs of rat hepatocytes. J Cell Biol, 1986, 103, 135-144.

13. Wang HZ, Veenstra RD: Monovalent ion selectivity sequences of the rat connexin 43 gap junction channel. J Gen Physiol, 1997, 109, 491-507.

Received: October 11, 2012; in the revised form: May 22, 2013; accepted: June 11, 2013. 